@CEDA/TU, 2017, US Library of Congress, Catalog Card No.: 79-915209, ISSN: 2091-0339

The Journal of Development and Administrative Studies (JODAS), Volume 25(1-2), pp.36-46

\title{
Employment Status of Women in Tourism at Pokhara, Nepal
}

\begin{abstract}
Laxmi Kanta Sharma ${ }^{1}$
Abstract

The employment generation from Pokhara as an established tourism destination in Nepal carries special significance in evaluating economic impact. This study aims to explore female employment status and influencing factors for the participation of women in tourism at Pokhara. A total of 250 respondents were sampled from ten tourism enterprises and ten in-depth interviews were conducted in order to gather primary data. Demographic factors such as age and marital status; socio-economic factors like educational level, work environment have been identified as independent variables that might have effect on women's level of participation. The findings reveled that women's participation in managerial position is low (31\%) comparing to the operative level (69\%). About 75 percent of employed women are moderately satisfied indicating the urgent need of improvement in working environment. The percentage of women employment lies only between minimum 20 to maximum 45 percent indicating the urgent need of trainings and skill development on women. The training on women has been found a noteworthy impacting factor for employment creation. The outcome of the study has positive implication on policy formulation for women employment in tourism sector.
\end{abstract}

Keywords: women employment, tourism enterprises, gender-constraints, socio-economic and demographic factors.

\section{Introduction}

Tourism industry is the greatest and quickly developing service sector on the planet with an average female participation of $55.5 \%$ in the global context and up to $70 \%$ at regional level (including hotel, tourism and catering sector). They are employed in a wide variety of roles, such as cleaners and kitchen staff, front-line customer service workers and in senior managerial posts. The status of women in the hospitality industry has been a concern among both management practitioners and academicians in the present setting (Baum,2013).Tourism industry is one of the major sources of Nepalese economy and its economic benefits can be achieved through a varieties of ways, like; direct, indirect and induced income; improvement in standard of living; generations of new employment opportunities, improvement in infrastructural facilities and development of local enterprises (WTTC,2018).Tourism industry is growing day by day in Nepal and women are gradually being encouraged to involve themselves in tourism and its related industries. But their number and position are far behind their male counterparts. In most cases their labor contribution is not accounted because they are mostly involved in indirect tourism business. The social, economic, attitudinal, financial, institutional, legal and political obstacles hamper them to move ahead and initiate their business and receive maximum benefits as per their input and potential. Nepalese women have greater potentiality in different tourism sectors like Rural Tourism, Village and Agro

\footnotetext{
${ }^{1}$ Mr. Sharma is an Associate Professor at Center for Economic Development and Administration (CEDA), Tribhuvan University, Kirtipur.

Corresponding mail: laxmikantas@gmail.com
} 
Tourism, Medical and Health Care Tourism and Eco-Tourism (Andres, Dasgupta, Joseph, Abraham \& Corriea, 2017).

Tourism industry is a labor intensive service industry, which provides a lot of employment to the people at different levels and sectors. The industry encompasses all activities by individuals, companies or organizations which supply directly or indirectly, goods or services to tourist at their destination(Jackson, 1995).Other than the positive parts of tourism industry, employment in the hospitality and tourism area is generally connected with lower quality of employment opportunities than different businesses (García-Pozo, Campos-Soria, SánchezOllero, \& Marchante-Lara, 2012; Lacher \& Oh, 2012). Lower salaries, more part-time and temporary contracts(Blake, Arbache, Sinclair, \& Teles, 2008; Lacher \& Oh, 2012)and the need to cover every minute of every day working hours (Lu \& Adler, 2009), may be the reasons why numerous employees desire to leave the business after their fundamental work experiences(Doherty, Guerrier, Jamieson, Lashley, \& Lockwood, 2001; Jenkins, 2001). Furthermore, literature in women in tourism demonstrates that tourism can disregard women rights, but it can also be used to challenge traditional roles and to empower women, in economic, social, cultural and political terms(Sijtsman, 2001). A study conducted by Daddi (2002) mentioned that tourism's low skilled employments were seen as great open doors for women and ethnic minorities. Shrestha (2000) specified the association of Nepalese ladies particularly Sherpas in mountain tourism through pottering and cooking during 1920s and1930s. It was the starting time of mountain tourism in Nepal. Since then, women have shown huge hospitality to tourists through producing handicrafts, cooking and conducting cultural performances. Mountain tourism is the pioneer of all the tourism in Nepal that began from 1949, the year Nepal opened for visitors.

It is broadly trusted that the employment opportunities produced by tourism industry is probably going to be higher in developing nations than in developed nations (Shrestha, 2000). As a employment provider, the role of tourism sector in Nepal is more significant. "Tourism directly/indirectly employees 945,000 jobs (6.4\% of total employment) in Nepal in 2017". This is expected to ascend by 6.0\% in 2017 (WTTC, 2018). Women's considerable participation in tourism industry of Nepal can undoubtedly play a remarkable role in women's empowerment. Various associations like National Trust for Nature Conservation(NTC), International Center for Integrated Mountain Development (ICIMOD), Tourism for Rural Poverty Alleviation Program (TRPAP), Nepal Tourism Board (NTB), Kathmandu Environment Education Project (KEEP), Annapurna Conservation Area Project (ACAP), Mother's Club Central Committee (MCCC), Women Entrepreneurs Association of Nepal (WEAN), United Nations Development Program (UNDP), International Labor Organization (ILO), Nepal Academy of Tourism and Hospitality Management (NATHAM) and Three Sisters Adventure Trekking (P) Ltd. and so on are observed to be engaged with improving women's participation in mountain tourism. These associations through their constant exertion in past and present periods have been creating awareness about local women's potentials in tourism, enabling them by offering training and capacity building activities and expanding their contributions in mountain tourism.

A report published by Nepal Academy of Tourism and Hotel Management (NATHAM) uncovers that a sum of 30,609 individuals had taken different academic courses and skill trainings during 1972-2011 at Nepal Academy of Tourism and Hotel Management. The quantity of women involvement in those courses was just 4,723 (15.43\%). In spite of the fact that women's participation is still very few in terms of number, they have reached a stage today where female trek leaders are leading solo women tourist trekkers, working as team 
leaders in mountain expeditions and operating hotels, lodges, restaurants, trekking and travel agencies from the top management positions.

Tourism has appeared as a new potential part for employment generation in Pokhara. The entry of women in the tourism business of Pokhara is an ongoing phenomenon which began just from 1988. At that time women had to struggle hard for their entrepreneurship in tourism, which was mostly captured by males (Upreti, Upadhayaya, \& Sapkota, 2013). Three sister trekking agencies situated in Pokhara, run since 1994 by Lucky, Dicky and Nicky Chhetri, three Nepalese sisters, are pioneers in the profession of female trekking guides.

Previous researches have discussed greatly on socio-cultural, economic and environmental aspects of tourism sector but only countable research works have focused on the women's participation in tourism industry and their level of satisfaction. This study deals with the types of tourism enterprises located in the Lakeside, Pokhara as well as the gender based employment status in the business. Furthermore, research aims to determine the influencing factor for the participation of women in tourism business and understand the level of satisfaction with their work. In this regard, this study will be valuable for the tourism industry related professionals, policymakers, planners, researchers and concerned stakeholders.

The remaining of the paper is structured as follows. Section 2 discusses relevant literature review. Section 3 discusses the methodology. The result and discussion of the findings are discussed in section 4 . Section 5 concludes the paper.

\section{Literature Review}

Shrestha (2000) investigated women's socio-economic condition in travel agency in tourism industry of Nepal. The results showed that these days more women workers are educated and are drawing a handsome remuneration. Women were encouraged from family and were observed to be more satisfied with their professions than men.WTO Public symposium 2005 report demonstrates that "women have an important role in the tourism sectors, accounting for up to $70 \%$ of the labor force in global tourism. However, their labor is often exploited and women get themselves amassed in casual labor force and low paying employments"(WTO, 2005). A study was carried out in Pokhara by Tourism Office in 2005 regarding women's direct participation in employment in the tourism business and it was found that around $21.5 \%$ females were involved in the tourism businesses comparing to men (Tourism Office, 2005).

In particular reference to the tourism and hospitality industry, men are paid more than women in nations like Czech Republic and Norway (Jurajda, 2003; Thrane, 2008). On account of Turkish hospitality industry, several researchers contend that women earn less because they usually find job in low-skilled and low-status positions with a lower compensation, for example, housekeeping(Aykac, 2006; Cave \& Kilic, 2010).As indicated by (ILO,2009,April), women in the expert field today hold greater positions of power than at any place throughout the world. Yet they still hold comparatively few and lower positions. Women today are paid like never before. Still, they are often paid less based on gender. Similar situation prevails in Nepal where constitution is proactive and provides for equality of opportunity and guarantee equality of sexes and in fact grants special favor to women at present context. 
An investigation was conducted on socio-economic status of women participating in tourism by Pahari (2008). This examination reports that most women employee are under $10+2$ level in education, married, and engaged in limited familial trade. It unveils the dissatisfaction of women in tourism business because of low pay, work load and longer working hours. Women in this sector have to confront the economic and language issue other than their occasional suffering from the crimes like robbery, theft and murder. They also have to undergo problems related to gender discrimination. Dhital (2009) has conducted a survey with employers from various sector of tourism. Out of 276 total employees, $14.1 \%$ were female. Among the total female employees, 48.7 percent were working in fundamental level followed middle level by 38.5 percent and high level by 12.8 percent. The survey explored that only 7.3 percent female employees were satisfied with their salary and facilities but rest of the others appeared to be unsatisfied. 22.7 percent female employees were satisfied in their job while roughly 78 percent appears to be totally unsatisfied and partially unsatisfied. Male domination, sexual harassment, sexual discrimination, insecurity and unsafe, social and family helplessness were the significant issues in female employment. Furthermore, there was absence of quality education and employment oriented trainings for the female.

Acharya(2010) conducted a study in Pokhara with the aim to understand women participation in tourism business. The study identified positive changes with some exciting pictures. Satisfaction of women in travel, tour and trekking subsectors was noted because of independency in finance. Women involvement in tourism was negatively taken in the past. At present, women are encouraged and have found positive attitude of society. Women from single family, unmarried, 20 to 30 years of age group were highly engaged in tourism. Gender equality in Indian hotel industry - a study of perception of male and female employees was conducted by Chaudhary\& Gupta (2010). Researchers illustrated that women are employed in regions where less physical work is required. Females need to attempt additional endeavors to demonstrate and unmarried and young ladies are favored in this industry. However, married women with children may be discriminated against even at the hiring stage(Chaudhary \& Gupta, 2010).

Tourism's low skilled employments were seen as great open doors for women and ethnic minorities. The literature on women employment status in tourism industry is the subject of social science, especially women research, management, anthropology, psychology and human geography(Chaudhary \& Gupta, 2010). Tourism employment survey was conducted by Ministry of Culture, Tourism and Civil Aviation in 2014 in 193 tourism industries of ten districts(MoCTCA, 2014) of Nepal. The survey revealed that about 5\% of the tourism personnel were self-employed and $95 \%$ of the personnel were employees. About four out of five $(80 \%)$ workers were male and only one-fifth were female $(20 \%)$. The proportion of females $(26 \%)$ was higher among the self-employed than among employees (19\%).

In all types of tourism enterprises the female employment percentage is low. The proportion of female workers was, therefore, highest in accommodation industries, followed by other (paragliding, ultra-light, skydiving) industries, airlines, travel agencies, trekking agencies and rafting agencies. Overall, 59 persons were employed on average in every tourism enterprises. Average employment generated by the industry was highest in international airlines (442); followed by domestic airlines (394), star hotels (128), tourist standard hotels (43), trekking agencies (29), rafting agency (15), home stay (12) and travel agency (12).Distribution of employment by gender and industry type is also shown in following figure 1. 
Figure 1: Distribution of Employment by Gender and Enterprise Type.

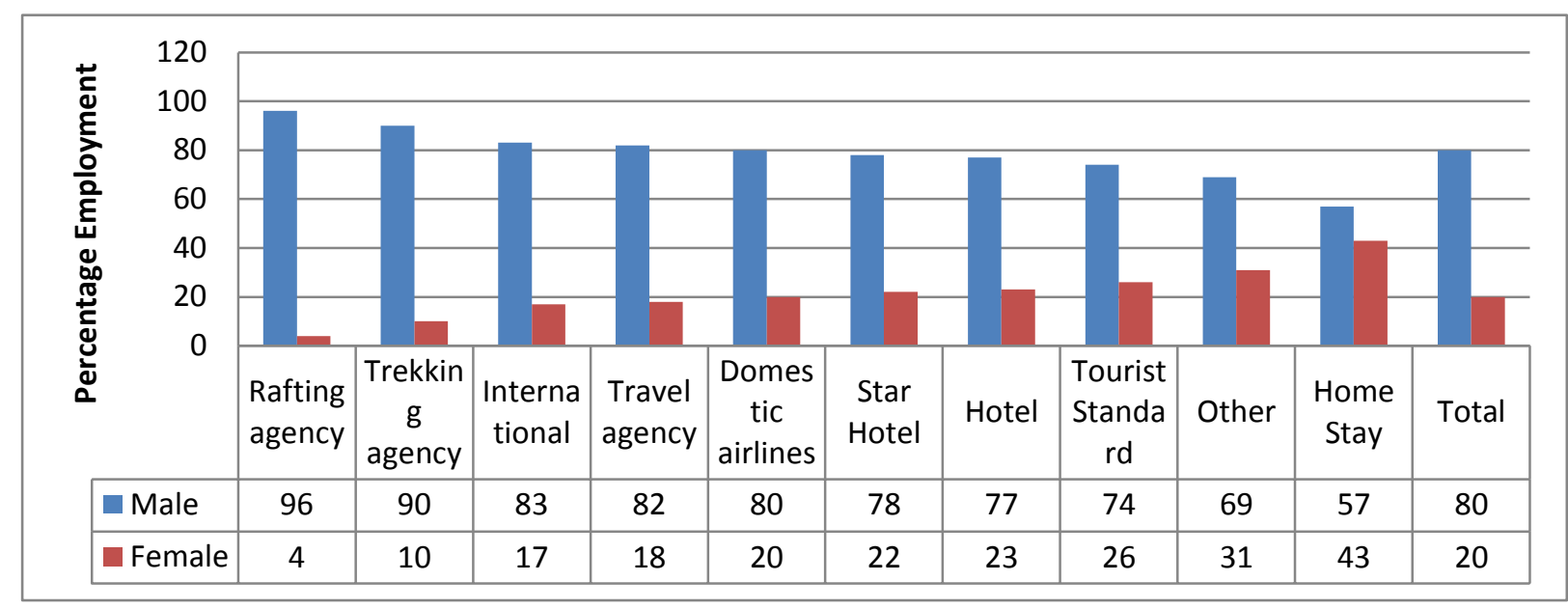

\section{Source: Nepal Tourism Employment Survey, 2014.}

Women in work are over represented in a limited scope of sectors and occupations. In uppermiddle-income countries, more than one third of women are employed in wholesale and retail trade services (33.9 per cent) and in the manufacturing sector (12.4 percent). In highincome nations, the significant source of employment for women is the health and education sector, which employs just about 33\% of all women in the labor market (30.6 per cent). Agriculture remains the most important source of work for women in low-wage and lowermiddle-income nations. In Southern Asia and sub-Saharan Africa, more than 60 percent of every working women remain in agriculture, frequently concentrated in time and laborintensive activities, which are unpaid or poorly remunerated (ILO, 2016).

The ILO (2016) featured the difficulties faced by women in the Hotel, catering and Tourism workplace. Unskilled or semi-skilled women tend to work in the most vulnerable employments, where they are more probably experienced poor working conditions, inequality of opportunity and treatment, violence, abuse, stress and sexual harassment. This appraisal is supported by various corresponding sources, notably by the United Nations World Tourism Organization (UNWTO, 2011) in a report that highlights both opportunities and challenges which face women with respect to employment in tourism. The majority of workers are women and wages are low compared to other sectors(ILO,2013).

Status of women in the present world scenario explicates that female are still far from enjoying the same basic rights, privileges and benefits that men do. Female labor force participation is low around the world. Just over half of women of working age are participating in the labor force. This varies from about 30\% in South Asia to more than $60 \%$ in Sub-Saharan Africa. Globally, women earn less than men. Women who are working generate on average $37 \%$ of the world's GDP. In some regions, this contribution is even lower. The share of regional economic output generated by women in India is only $17 \%$ of the national output. In the Middle East, North Africa (MENA) region it is $18 \%$. In North America and Oceania, China, and Europe and Central Asia, women generate 40-41\% of the GDP(WBG, 2017).

In Nepal, tourism has been considered an important sector for its potential contribution to strengthen national economy, gender inclusion, improvement of the quality of lives and poverty alleviations by generating employment opportunities and foreign exchange earnings. 
Luis \& Colleague (2017) in World Bank research paper found that women labour force employment is $79.9 \%$ in Nepal. It is highest among three countries.

The paper shows that while the female workforce is rising in most parts of the world, it is sliding in India. Just 27\% of working age women were employed in 2015-2016. In Nepal, women labor force employment is $79.9 \%$ while in Bangladesh it is $57.4 \%$ which is miles ahead of us. Only Pakistan, at $24.6 \%$, has a lower rate. Apart from parts of the Arab world, everywhere else more women are working. China, with its vibrant economy, has $64 \%$ of its women working, one of the highest rates in the world. In the US, it is over 56\%.According to economist Jayan Jose Thomas of IIT Delhi felt the key reason for increasing joblessness among Indian women is that there are not enough jobs.

The common gender constraints to employment are wage gaps, inadequate workplace policies and conditions, inadequate skills, lack of upward mobility, lack of childcare or flexible work schedule options, gender related problems e.g. sexual harassment, sex -related entertainment. Previous studies were carried out in certain enterprises but this study covers whole lakeside area of Pokhara in ten different enterprises, in this sense the study is different and unique than other studies.

\section{Methodology}

Pokhara, the tourism capital of western region, situated 200 kilometers south-west of Kathmandu. Pokhara is a complete in itself having all kinds of experiences where nature and cultural blend wonderfully show a staggering scene unparalleled anywhere else. It is a famous traveler destination where numerous direct and indirect suppliers of goods and services to the incoming tourists are in existence with high probability of employment to both men and women. Lakeside, the primary tourist region in the valley is arranged at the eastwest part of Pokhara and a large portion of the tourism business areas including hotels, restaurants, travel and trekking agencies and so on are situated here.

The survey conducted by Sharma (2011) was utilized to gather information on numbers of tourism businesses (hotels and lodge, guest house, restaurant, tea and coffee shops, laundry, massage center, money changer, bakery shop, yoga and meditation and communication services) associated in Pokhara. The survey was conducted between Jan-Feb, 2017. Each tourism business enterprises were visited for the face to face questionnaire and interview.

To ensure a representative sample based on number of employees in tourism business, population was sampled by quota sampling technique. From ten different enterprises altogether 250 respondents were selected based on the number of members of their professional organizations. Semi structured questionnaire were utilized to collect data. All the questions were pre- tested and revised before collecting data. Different PRA techniques involving Focus Group Discussion (FGD) and In-depth Interview (IDI) were used to collect the qualitative data. In this study, the socio-demographic variables consist of age, gender, marital status, education level and type of work. Eight age groups: 15-19, 20-24, 25-29, 29$34,34-39,39-44,44-49$ or more were incorporated.

All the sampled female respondents (250respondents) from 10 tourism business sector in the lakeside region were asked questions by concentrating on type of work, level of participation and satisfaction with work. Other than these, 10 in-depth Interviews (IDI) were conducted with the manager of the selected tourism enterprises. 
The information gathered from the field survey were checked for culmination and accuracy, and afterward coded for analysis. The SPSS version 20 was utilized to ascertain rate for all indicators. Significance tests have been carried out to determine the association between women's level of participation with different covariates utilizing Chi-square test. Each independent variable for example, demographic and socioeconomic have been cross tabulated with women's level of participation. Multivariate analysis has not been carried out due to insufficiency of cases.

\section{Results and Discussion}

\subsection{Demographic and socioeconomic characteristics of the respondents}

The major demographic factors as independent variables used in this survey consist of age and marital status of the women. The age was found varied from 17 years to 52 years. Major percentage of the women (30\%) were 20-24 aged, $27 \%$ were with age group of 25-29. Only $3 \%$ of women were above 49 years. Majority of female workers in tourism sector are married with percentage share of $66 \%$.

Table 1: Distribution of Respondents by Their Demographic and Social Factor

\begin{tabular}{|c|c|c|}
\hline Variables & Categories & Percentage \\
\hline \multirow[t]{8}{*}{ Age } & $15-19$ & 5 \\
\hline & $20-24$ & 30 \\
\hline & $25-29$ & 27 \\
\hline & $30-34$ & 19 \\
\hline & $35-39$ & 5 \\
\hline & $40-44$ & 6 \\
\hline & $45-49$ & 5 \\
\hline & Above 50 & 3 \\
\hline \multirow[t]{2}{*}{ Marital Status } & Unmarried & 34 \\
\hline & Married & 66 \\
\hline \multirow[t]{6}{*}{ Educational Level } & Primary & 29 \\
\hline & Lower secondary & 24 \\
\hline & Secondary School & 19 \\
\hline & +2 Level & 15 \\
\hline & Bachelor & 7 \\
\hline & Above Bachelor & 6 \\
\hline \multirow[t]{3}{*}{ Satisfaction with Work environment } & High & 15 \\
\hline & Medium & 75 \\
\hline & Low & 10 \\
\hline \multirow[t]{2}{*}{ Women's Participation Level (position) } & Managerial & 31 \\
\hline & Non Managerial & 69 \\
\hline
\end{tabular}

Source: Field Survey, 2017

Data demonstrates that as age increases the participation of women in tourism industry becomes lower. Additionally, the women under the lowest age group 15-19 have also very low participation $(5 \%)$. It indicates that tourism sectors prefer women with maturity for employment. This revealed that both lower and higher age is not mostly preferred for the tourism employment. However, the lower age is found much preferable contrasting with the higher one. With regard to marital status, $64 \%$ of women were married. Generally, it is seen that tourism industry prefers to employ unmarried women because an unmarried lady can give time for various working shifts compared with married one. However, this study has shown the contrast findings. Out of 38 ladies 21 have got married during the age group 2024.Similarly, under the age group 25-29 all 26 women were married. Thus with the increase in age of employment, the married women's proportion becomes higher. 
The socio economic factors included in this study are: education level, satisfaction with work life and women's participation level. With respect to the education level, it is found that the vast majority of the female (29\%) engaged with the tourism business have just primary level of education. Education of female up to lower secondary, secondary, +2 , bachelor and above consists of $24 \%, 19 \%, 15 \%, 7 \%$ and $6 \%$ individually (table 1). As a large portion of the tourism business sectors in Pokhara area are running as a family business where hotels are not the exception in this regard. Not only women with the primary level of education, however, higher than that level as well, it is found that the majority of them were working in the lower level positions. It is because of the lower level of education that they have.

Work environment is divided into two perspectives either favorable or unfavorable. Unfavorable work environment may at last lead an employee to leave the job. This study revealed the different level of satisfaction from the work environment in tourism sector. $75 \%$ respondents reacted the medium level of satisfaction, $15 \%$ reacted the high level of satisfaction and just $10 \%$ reacted the low level of satisfaction from their work environment (Table 1).Similarly, the outcome demonstrates that $69 \%$ of the ladies were participated in non- managerial level whereas less than one third $31 \%$ were associated with managerial position with age group 29-35 and are married.

Marital status of women has significant impact with their level of participation in tourism industry. Tourism industry particularly hotels prefer an unmarried ladies for the front positions that need to deal the visitors specifically. Not only for this reason, hotels prefer an unmarried women who can give time even for the night shifts and early morning shifts which is an exceptionally troublesome circumstance for a married women to manage. But, for the higher positions, particularly for the managerial positions, it is additionally observed that the tourism sector prefers matured and experienced women who generally are married. Likewise, for the backhouse positions and one timework hotels prefer married women also. The study demonstrates that women with managerial level participation who were unmarried are around $43 \%$ and it was just $25 \%$ among the married women. Similarly, around $75 \%$ operative level women were married and $57 \%$ were unmarried. Hence, the test demonstrates that unmarried women will probably have higher level of participation.

Most significant number of women participating in non-managerial level were employed for front position to deal with visitor remarkably in hotels, guest house and restaurant. This study has discovered that women with higher education level have higher number of participation in the higher level positions.

\subsection{Businesswise Employment Structure by Gender}

Employment in different businesses located in Lakeside Pokhara with the number of employees is presented in figure 2. Out of the ten businesses, maximum number of hotel and lodge exist in the study area with large number of male employees. Among all business type male percentage of employment was higher ranging from $55 \%$ to $80 \%$ whereas female employee percentage was ranging only from $20 \%$ to $45 \%$ (highest) in Guest House, Tea and Coffee Shops. Low level of female employment was found in Yoga and Meditation Center (20\%). Out of total employees, 65 percent employees were found males and 35 percent only were females. Women were mostly preferred for employment in Guest House, Restaurant and Tea and Coffee Shops. 
Figure 2:Distribution of Employment (\%) by Gender and Business Type

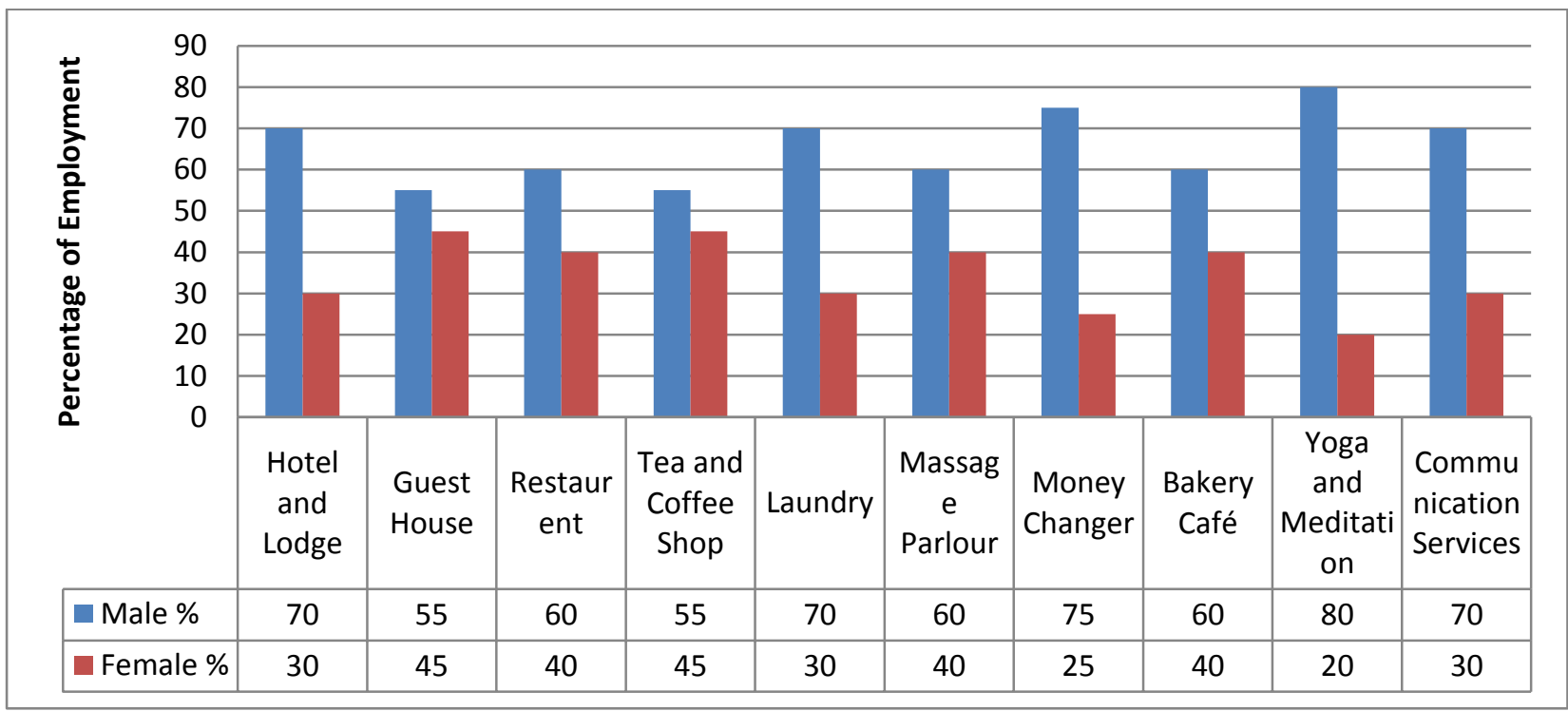

Source: Field Survey 2017, Pokhara.

\section{Concluding Remarks}

Among the employed women about $76 \%$ belong to 20-34 years of age group and this figure indicates that young women of productive age group are involved in tourism. Similarly, 66 percentage of employed women are married against 34 percentage of unmarried women. This is contrasting result in tourism sector because young and unmarried are mostly preferred in private sector tourism enterprises. The reason behind this may be the unavailability of skilled workers and high frequency of job change in the sector.

Another interesting findings is that 75 percentage of employed women are moderately satisfied indicating high level of dissatisfaction among workers. The working environment should be improved in order to increase the level of happiness among workers. Looking at the participation of women in senior level management position, there is only 31 percentage which signals the gender inequality in tourism employment. It might be due to the low level of education among employed women, where there is about $87 \%$ women have plus two and lower level of education.

However, looking from another prospective, 13 percent women who have bachelor and above level of education holding 31 percentage of senior positions is a great achievement. In all business enterprises, the percentage of women employment ranges only between minimum 20 to maximum 45 percentage whereas it is 55 to 80 percentage for male. So there is major dominance of male employment in all enterprises. In order to increase women's participation, women are to be trained with more managerial skill along with higher academic degree.

In conclusion, the study revealed that demographic factors have no strong influence on women's level of participation. However, socioeconomic factors have found high influence on women's participation. The training on women has been observed a noteworthy impacting factor for employment creation. Contrary to the previous studies, this study found that the percentage of married women employment was higher than unmarried. 
The outcome has demonstrated that only with the higher level of education, the higher level of employment in senior positions can be achieved. Therefore, it is recommended to increase women's capability and confidence for tourism enterprises through supportive social, economic and legal schemes.

\section{References}

Acharya, S. (2010). Women's participation in tourism business (Unpublished master's thesis).Tribhuvan University, Kathmandu.

Andres,L.A.,Dasgupta B.,Joseph,G.,Abraham,V\&Correia,M.(2017,April). Reassessing patterns of female labour force participation (Policy research working paper 8024).World Bank Group, South Asia Region,Social Development Unit.

Aykac, A. (2006).Linking scale of operation and labor transformation on tourism: Comparative analysis on three Turkish cases. Anatolia, 17(2), 257-277.

Baum,T.(2013). International perspectives on women and work in hotels, catering and Tourism(Working paper). Geneva: ILO.

Blake, A., Arbache, J. S., Sinclair, M. T., \& Teles, V. (2008). Tourism and poverty relief. Annals of Tourism Research, 35(1), 107-126.

Cave, P., \& Kilic, S. (2010).The role of women in tourism employment with special reference to Antalya, Turkey. Journal of Hospitality Marketing \& Management, 19(3), 280-292.

Chaudhary, M., \& Gupta, M. (2010). Gender Equality in Indian Hotel Industry--a study of perception of male and female employees. International Journal of Hospitality \& Tourism Systems, 3(1).

Daddi, S. (2002).Fem-treks: Practicing feminist tourism in Nepal (Unpublished master's dissertation). Barnard Collage, USA.

Dhital, J. N. (2009). Tourism in Nepal: problems and prospects of female employmen(Unpublished doctoraldissertation). Tribhuvan University, Kathmandu.

Doherty, L., Guerrier, Y., Jamieson, S., Lashley, C., \& Lockwood, A. (2001).Getting ahead: Graduate careers in hospitality management. London: Higher Education Funding Council for England and the Council for Hospitality Management Education.

García-Pozo, A., Campos-Soria, J. A., Sánchez-Ollero, J. L., \& Marchante-Lara, M. (2012). The regional wage gap in the Spanish hospitality sector based on a gender perspective. International Journal of Hospitality Management, 31(1), 266-275.

ILO. (2016). Women at work trend. Geneva: ILO.

ILO.(2009,April). World of work:The magazine of the ILO, 65,Geneva ,ILO.

Jenkins, A. (2001). Making a career of it? Hospitality students' future perspectives: An Anglo-Dutch study. International Journal of Contemporary Hospitality Management, 13(1), 13-20.

Jurajda, Š. (2003). Gender wage gap and segregation in enterprises and the public sector in late transition countries. Journal of comparative Economics, 31(2), 199-222.

Lacher, R. G., \& Oh, C.-O. (2012).Is tourism a low-income industry? Evidence from three coastal regions. Journal of Travel Research, 51(4), 464-472.

Lu,T., \& Adler, H. (2009). Career goals and expectations of hospitality and tourism students in China. Journal of Teaching in Travel \& Tourism, 9(1-2), 63-80.

Luis A. and Colleague(2017).The world Bank Paper (September, 2017).London: World Bank.

MoCTCA. (2014). Tourism Employment Survey 2014. Kathmandu: MoCTCA. 
Pahari, J. (2008). Socio-economic status of women participation in tourism industry, A case study of women of Lakeside-6, Pokhara (Unpublished M.A.thesis). Tribhuvan University, Kathmandu, Nepal.

Sharma, L. K. (2011). An analysis of employment and investment in tourism industry: A case study of Pokhara (Unpublished M.Phil's thesis).Tribhuvan University, Kathmandu.

Sijtsman, W. (2001). Tourism training development for women's empowerment: An amendatory methodology (Unpublished master's dissertation). Netherlands Institute of Tourism and Transport Studies,Netherlands.

Thrane, C. (2008).Earnings differentiation in the tourism industry: Gender, human capital and socio-demographic effects. Tourism Management, 29(3), 514-524.

Tourism Office (2005). Information brochure 2005. Pokhara:Tourism Office.

UNWTO. (2011). Global Report on Women in Tourism 2010. Madrid: UNWTO.

Upreti, B. R., Upadhayaya, P. K., \& Sapkota, T. (Eds.). (2013).Tourism in Pokhara: Issues, trends and future prospects for peace and prosperity.Kathmandu: Pokhara Tourism Council, Pokhara.

WBG. (2017). Tourism for development. Washington, DC: World Bank Group.

WTTC. (2018). Travel and Tourism :Economic Impact 2018,Nepal. London: WTTC.

Jackson, I. (1995). An introduction to tourism. Melbourne: Hospitality Press.

Shrestha, H. P. (2000). Tourism in Nepal: Marketing challenges. New Delhi: Niraula Publications. 